\title{
Pemanfaatan Fasilitas Google dalam Perkuliahan di Fakultas Dakwah Surya Eka Priyatna
}

Fakultas Dakwah dan Komunikasi IAIN Antasari Banjarmasin

\begin{abstract}
In the course we are familiar with the Internet network facilities. Of course also familiar with the Google search engine. But we rarely use the other facilities there, which turned out to be very belpful in learning activities. Company Google intelligently integrates most of the processing functions of administrative data in applications, such as mail, drive, document, spreadsheet, slide and form. Such products can we maximize the efficiency and effectiveness of lectures.
\end{abstract}

Keywords : Internet, google, administrative, applications

Pada perkuliaban kita sudah familiar dengan fasilitas jaringan internet. Sudab tentu juga familiar dengan mesin pencari google. Tetapi kita jarang menggunakan fasilitas-fasilitas lainnya yang ada, yang ternyata sangat membantu dalam kegiatan perkuliahan. Perusahaan Google dengan cerdas mengintegrasikan sebagian besar fungsi-fungsi pengolahan data administratif dalam aplikasinya, seperti mail, drive, document, spreadsheet, slide dan form. Produk-produk tersebut dapat kita maksimalkan untuk efisiensi dan efektifitas perkuliahan.

Kata kunci : internet, google, administratif, aplikasi

\section{A. Pendahuluan}

Dalam perkuliahan, seringkali para pengajar mengalami kesulitan dalam media pengajaran. Problem yang paling sering dihadapi adalah sistem komputer yang error yang diakibatkan oleh fungsi aplikasi yang gagal terbuka atau dirusak sistemnya oleh virus. Terkadang materi yang berupa file sering terhapus dengan tidak sengaja. Hal tersebut menjadi hal klasik yang sangat menggangu pengajaran.

Google dalam kalangan akademisi sudah sangat familiar digunakan, namun terbatas pada fasilitas populer yakni pencarian data di internet. Dalam jurnal ini kita akan mengupas lebih banyak kelebihan dan kemudahan yang diberikan google jika kita mau maksimal menggunakannya. Aplikasi Legal

Sudah menjadi rahasia umum bahwa penggunaan sistem operasi windows di negara kita sangat familiar dalam penggunaan, tetapi sebagian dari kita masih menggunakan aplikasi tersebut secara ilegal atau dengan istilah versi bajakan. Tentu bagi kaum pendidik sebenarnya ini merupakan suatu hal yang tidak etis, karena memakai sesuatu yang tidak legal. Sebenarnya sudah banyak sistem operasi lain yang gratis yang sudah dikembangkan yang berbasis Linux, seperti ubuntu, freebsd, redhat dan sebagainya.
Namun belum begitu populer karena beralih ke sistem yang harus meluangkan waktu khusus untuk belajar dari awal tidak diminati oleh sebagian orang.

\section{B. Pembahasan}

\section{Produk Google}

Dewasa ini google sudah melakukan inovasi berbasis kebutuhan pengguna, yang pada akhirnya menjadikan google sebagai tujuan utama para pengguna menggunakan internet. Google menyediakan mulai dari :

\section{Kategori web}

Kategori web ini berisi penyelusuran website, browser google chrome, dan fasilitas bookmark untuk penyimanan alamat website yang telah dikunjungi.

\section{Kategori Seluler}

Kategori seluler yang paling banyak diminati oleh pengguna, karena masa sekarang sistem frameware smartphone sebagian besar menggunakan aplikasi android terbitan google.

\section{Kategori Bisnis}

Kategori bisnis berisi produk adword, adsense dan admob, yang merupakan cara google interaksi bisnis dengan pelanggan, dengan syarat dan ketentuan yang berlaku menurut aturan google. 
Yang menjadi fokus kita adalah produk untuk kegiatan rumah dan kantor, yang didalamnya meliputi gmail, drive, dokumen, spreadsheet, slide, formulir, gambar, kalender, terjemahan, cloud print, google keep dan google hanguots. (gambar 1)
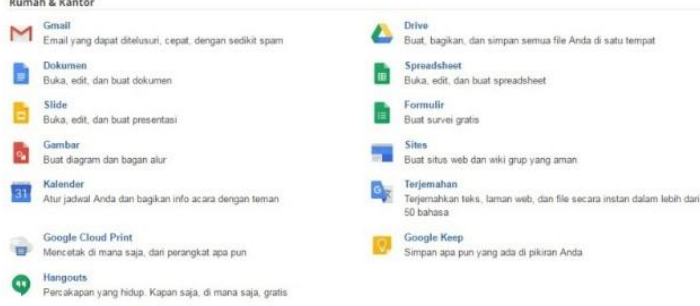

gambar 1. Produk google

\section{Google Drive}

Google Drive adalah penyimpanan data secara online selayaknya menyimpan ke dalam folder dalam komputer. Layanan ini juga terintegrasi dengan google mail dalam satu akun. Google Drive memberikan layanan penyimpanan gratis sebesar 15 GB dan dapat ditambahkan dengan pembayaran tertentu. Dengan fitur unggulan yang sama seperti Dropbox, yaitu sinkronisasi data melalui folder khusus di dalam desktop atau lebih dikenal dengan Desktop Sync Clients.

Google Drive memberikan kapasitas gratis sebesar 5 GB dan tentunya fitur-fitur yang terintegrasi dengan layanan Google lainnya seperti: Gmail, $G+$ dan Google Search. Fitur yang bisa digaris bawahi dari Goole Drive adalah API's untuk para pengembang. Hingga kini Google Drive telah terhubung dengan puluhan aplikasi terkait . (gambar 2)

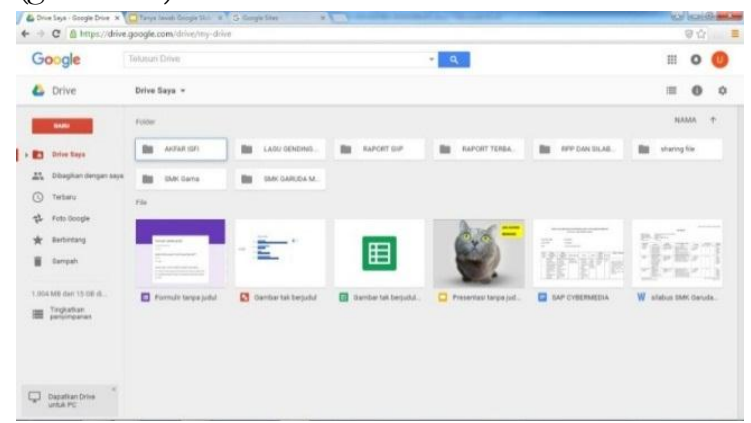

gambar 2. google drive

\section{Fungsi dari Google Drive}

Google Drive memiliki fungsi layaknya Dropbox yaitu sinkronisasi data dari komputer kita, jadi Kita bisa membuat dan berbagi data dan dokumen di google drive tersebut. Selain itu kita juga bisa mengakses data file dari mana saja di rumah ataupun di kantor dengan terhubung dengan internet pastinya.

Keuntungan lainnya yaitu Google Drive telah terintegrasi dengan layanan google liannya diantaranya gmail, Gplus, google search dan lainnya. Jika kita belum pernah mencoba google drive ini, silahkan langsung menuju drive.google.com lalu loginlah menggunakan Email kita agar kita bisa menggunakan Google Drive. Nanti akan tampil seperti gambar dibawah jika google drive kita sudah diaktifkan, namun jika belum silahkan tunggu pemberitahuan dari google ke email kita. Kalau sudah berhasil login dan Google Drive sudah aktif kita bisa langsung Upload File atau folder. Jika ingin menambah kapasitas penyimpanan di Google Drive kita diharuskan membayar beberapa dollar, sesuai dengan harga yang diberikan oleh google.

\section{Cara menggunakan Google Drive}

Kadang-kadang mudah untuk mengabaikan sesuatu yang tersedia dan dapat diakses secara gratis, contohnya Google Drive. Sepertinya apapun yang kita lakukan terhubung dengan Google. Kita tidak menyadari nilainya sampai kita benar-benar dekat dengannya. Salah satu cara menggunakan Google Drive yang benar adalah memahami cara mengelola file dan folder di layanan ini. Ini hal yang sederhana, namun ada beberapa tips yang bisa memaksimalkannya.

Ada banyak yang dapat Kita lakukan dengan penyimpanan gratis sebesar 15GB. Kita dapat melakukan lebih banyak ketika Kita menganggap bahwa Google Drive adalah suite produktivitas. Kita dapat menggunakan Google Drive untuk penelitian atau Kita dapat menggunakan Google Drive untuk penggunaan kreatif. Tetapi pada akhirnya, mengelola dengan baik berarti mengetahui cara menangani semua file dan folder yang Kita simpan di penyimpanan server google.

Google Drive adalah jejaring sosial yang memiliki fungsi untuk membuat dan berbagi data dan dokumen di Google Drive. Kita juga bisa 
mengakses data File darimana saja di rumah atau di kantor yang terhubung dengan Internet. Hal ini memberikan kemudahan dalam penyimpanan file penting yang sering digunakan tanpa harus takut akan kena virus ataupun terhapus dari komputer.

\section{Google Document}

Google memberikan alternatif bagi yang tetap menginginkan aplikasi sejenis bawaan sistem operasi windows seperti microsoft word tetapi legal, dengan menerbitkan google document. Sistem ini memerlukan koneksi jaringan internet dalam pengoperasiannya, namun tidak lagi harus menginstall programnya ke dalam desktop atau komputer pribadi.

Dalam google document memiliki menu edit, lihat, sisipkan, format, alat, tabel, pengaya, dan bantuan. (gambar 3)

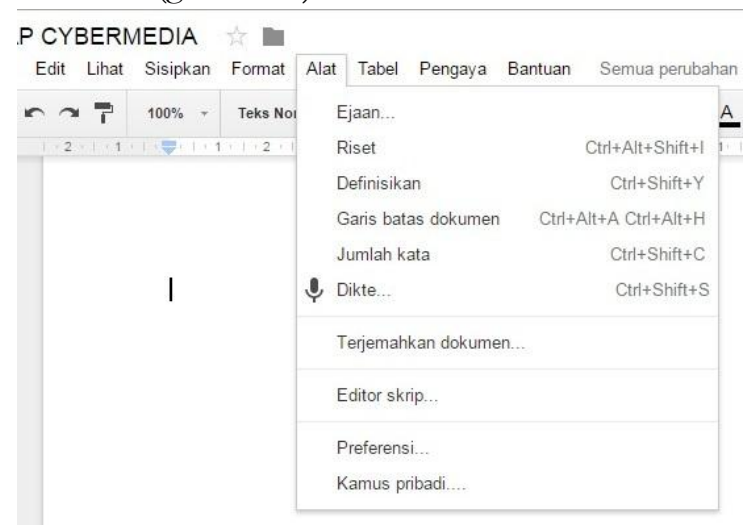

Gambar 3. Google document

Pengoperasiannya sangat mirip dengan microsoft dengan tambahan fungsi spsifik, seperti :

\section{Riset}

Riset merupakan fasilitas yang disediakan untuk mencari bahan referensi untuk tulisan kita. Aplikasi tersebut sudah terhubung dengan tulisan sehingga sudah dapat memberikan opsi sesuai dengan topik dari yang kita tulis.

\section{Definisi}

Fasilitas definisi merupakan alat untuk merekam istilah yang kita buat, untuk mengkategorikan sesuatu hal diluar istilah awam.

\section{Dikte}

Fasilitas dikte merupakan fasilitas canggih yang ditautkan ke aplikasi google document.
Prosedurnya adalah Speech to text. Fasilitas ini mampu mengubah verbal audio menjadi rangkaian kata bahkan kalimat. Prosedurnya memanfaatkan microphone yang ada di komputer kita kemudian diconvert ke teks.

Terdapat banyak pilihan dialek, dan bahasa Indonesia sudah masuk didalamnya. (gambar 4)

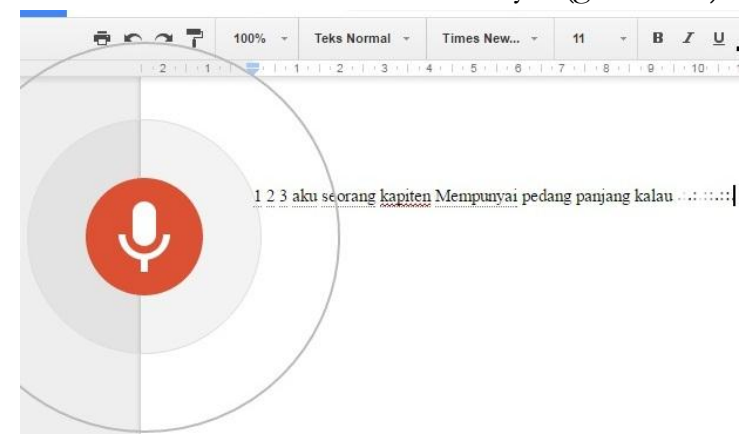

Gambar 4. Fasilitas dikte

\section{Google Slide}

Google slide merupakan fasilitas presentasi layaknya power point pada microsof office. Fasilitas ini sangat memberikan kemudahan dalam membuat presentasi, menampilkan presentasi, bahkan dapat berinteraksi antara presenter dengan pemirsa secara online.

File google slide dapat di share, dan presentasi dapat di diskusikan melalui media yang terhubung dengan google slide (gambar 5)

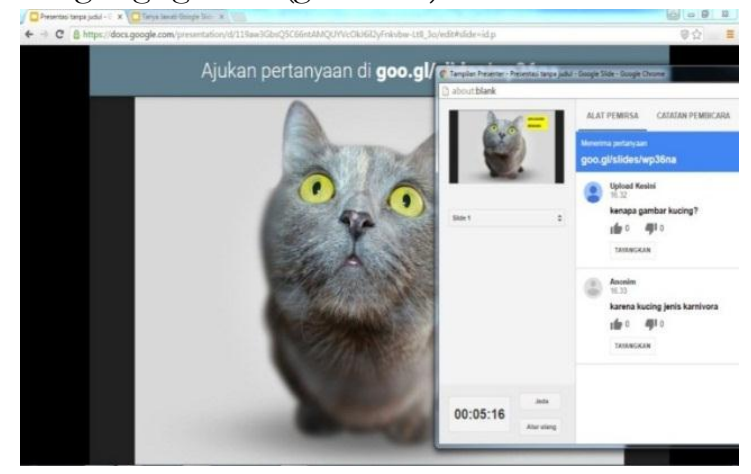

Gambar 5. Google slide

\section{Google Form}

Produk google form adalah fasilitas google untuk membuat survey secara online. Hal ini sangat berguna bagi interaksi pengajar dan mahasiswa dalam perkuliahan. Survey online dapat digunakan untuk memberikan masukan tentang keberhasilan perkuliahan atau materi yang sedang dibahas. Cara pembuatan formulirnya pun sangat sederhana (gambar 6) 


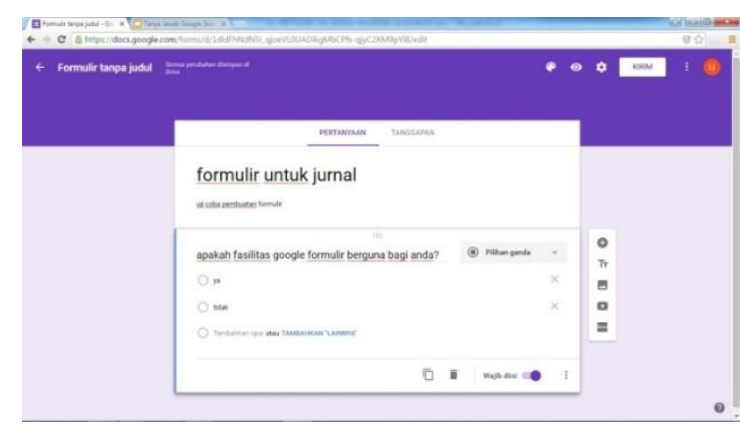

Gambar 6. Pembuatan formulir

Fasilitas ini juga dapat digunakan untuk asesmen dan evaluasi terhadap mahasiswa dalam perkuliahan kita. (gambar 7)

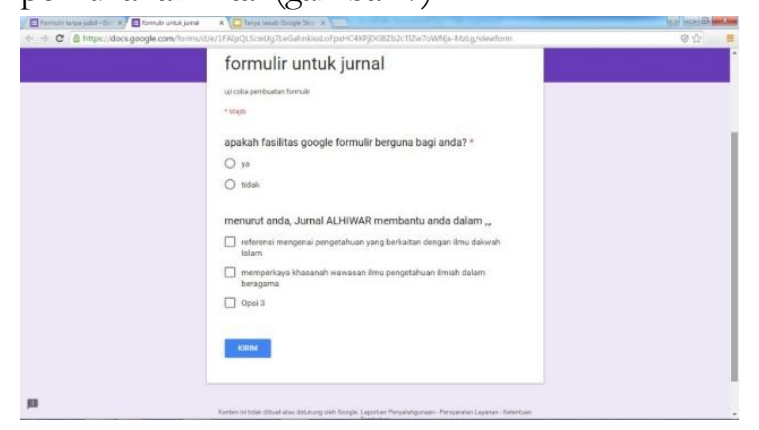

Gambar 7. Pratinjau formulir

\section{Kesimpulan}

Banyak fasilitas di dalam google yang dapat kita gunakan untuk menunjang perkuliahan, tentunya didukung oleh instalasi internet yang memadai.

Fasilitas yang terintegrasi membuat materi perkuliahan menjadi tertata rapi, tanpa ada kekhawatiran akan kerusakan data atau file yang diakibatkan oleh virus atau terhapus.

Penggunaan aplikasi google yang legal merupakan alternatif yang baik bagi para pengajar atau dosen yang sudah familiar dengan sistem operasi windows.

Memperbanyak interaksi dengan mahasiswa melalui fasilitas google sangat disarankan, sebagai upaya kampanye untuk meminimalisir penggunaan aplikasi ilegal.

\section{Referensi}

Abhinandan S. Das, 2007. Google news personalization: scalable online collaborative filtering WWW '07 Proceedings of the 16th international conference on World Wide Web Pages 271280 ACM New York, NY, USA

Battelle John, 2011. The Search How Google and Its Rivals Rewrote the Rules of Business and transformed our culture. Nicholas Brealey Publishing USA

Ghemawat, Sanjay, 2003 ; Gobioff, Howard ;Tak Leung, Shun, 2003 SOSP '03 Proceedings of the nineteenth ACM symposium on Operating systems principles Pages 29-43 ACM New York, NY, USA

Jarvis, Jeff, 2011. What Would Google Do?: Reverse-Engineering the Fastest Growing Company in the History of the World.Harper Business

Sparrow, Betsy , 2011. Google Effects on Memory: Cognitive Consequences of Having Information at Our Fingertips. Science 05 Aug 2011: Vol. 333, Issue 6043, pp. 776-778 